\title{
Review on properties of GGBFS and fly ash incorporated aerated concrete with filler materials.
}

\section{Revisión de las propiedades del hormigón celular GGBFS y cenizas volantes incorporadas con materiales de relleno.}

\author{
Jinu Darsh M.S., Indu Susan Raj, Dr. Elson John
}

Dept. of Civil Engineering, Mar Athanasius College of Engineering, Kothamangalam, Kerala, India. Corresponding author mail id:jinudarshms@gmail.com

\begin{abstract}
Light weight concrete has been an area of interest for a lot of researchers over the years. While reducing the weight of concrete, mechanical strength and durability should not be compromised. Use of GGBFS and fly ash as partial replacement of cementitious material has been proved effective from various studies previously done. Along with the weight reduction, waste recycling is also an important concern for the researchers. Various waste materials like plastic particles, quarry dust, rubber powder etc. are studied for their effectiveness as a partial replacement for fine aggregates. Common issue with most of the filler materials is the strength reduction occurring with their addition. Apart from mechanical strength tests, micro structure study on the specimens will help to analyse the effect of addition of each material in detail. Keywords- Aerated concrete, GGBFS, quarry dust, rubber powder, plastic particles.
\end{abstract}

\section{RESUMEN}

El hormigón ligero ha sido un área de interés para muchos investigadores a lo largo de los años. Si bien se reduce el peso del hormigón, la resistencia mecánica y la durabilidad no deben verse comprometidas. El uso de GGBFS y cenizas volantes como reemplazo parcial de material cementoso ha demostrado ser efectivo a partir de varios estudios realizados anteriormente. Junto con la reducción de peso, el reciclaje de residuos también es una preocupación importante para los investigadores. Se estudian diversos materiales de desecho como partículas de plástico, polvo de cantera, polvo de caucho, etc. para determinar su eficacia como sustituto parcial de los áridos finos. El problema común con la mayoría de los materiales de relleno es la reducción de resistencia que se produce con su adición. Además de las pruebas 
Sustainability, Agri, Food and Environmental Research, (ISSN: 0719-3726), 10(X), 2022:

http://dx.doi.org/

de resistencia mecánica, el estudio de la microestructura de las probetas ayudará a analizar en detalle el efecto de la adición de cada material. Palabras clave: hormigón celular, GGBFS, polvo de cantera, polvo de caucho, partículas de plástico.

\section{INTRODUCTION}

The density of the light weight concrete can be in ranges from 320 to $1920 \mathrm{~kg} / \mathrm{m}^{3}$. It can be used in multi storey buildings, long span bridges, offshore platforms and large structures. It has low density, low thermal conductivity, low shrinkage and high heat resistance in addition to reduction in dead load, lower haulage cost and faster building rate. Aeration in aerated concrete is done using aluminium powder. Similar to aerated concrete is foam concrete in which air voids are made using foaming agent. Aerated concrete can be of autoclaved or nonautoclaved aerated concrete. Studies proved that autoclaved aerated concrete has better mechanical properties than non-autoclaved aerated concrete. Autoclaved aerated concrete combines insulation and structural capability in one material for walls, floors, and roofs. Its light weight/cellular properties make it easy to cut, shave, and shape, accept nails and screws readily, and allow it to be routed to create chases for electrical conduits and smaller-diameter plumbing runs. This gives it design and construction flexibility, and the ability to make easy adjustments in the field. Autoclaved aerated concrete is a versatile light-weight creation material and typically used as blocks [Qu, Xiaoling, and Xuguang Zhao;2017.]. A low density and top notch insulation residences due to high porosity. The low density is carried out by way of the formation of air voids to provide a cellular shape [Chaipanich, A., and P. Chindaprasirt;2015]. The completed product is as much as five instances the volume of the raw materials used, with an air content of $70-80 \%$ (depending on the required power and density) without problems reasonable can be saved, nailed and drilled without problems even than timber.

\section{MATERIALS AND METHODS}

Various studies have proved that GGBFS (Ground Granulated Blast Furnace Slag) is very effective in improving the mechanical properties of concrete. GGBFS increased the compressive strength of AAC (Autoclaved Aerated Concrete) blocks by 172 \% [Pachideh, Ghasem, and Majid Gholhaki; 2019]. In the same study, replacement of $21 \%$ of cement by weight increased the tensile strength by $25 \%$. Water absorption was reduced by $45 \%$ with the addition of GGBFS. In the study by Pachideh et al, along with GGBFS, silica fume and zeolite too were analysed. Both of them improved the properties of AAC blocks similar to GGBFS. Among the three pozzolonas, silica fume was effective in improving the strength and reducing the water absorption than the others. Studies on the effect of GGBFS on aerated concrete are 
Sustainability, Agri, Food and Environmental Research, (ISSN: 0719-3726), 10(X), 2022:

http://dx.doi.org/

not extensive till now. Further studies are needed.

Plastic particles are found to be effective in resisting the drying shrinkage cracking of cementitious materials [Drochytka, Rostislav, and Ester Helanová, 2015]. But the addition of plastic particles couldn't improve the mechanical properties of mortar. With increase in plastic particle amount the split tensile strength and flexural strength of mortar specimens were reduced significantly. At the interface between plastic and cement matrix, due to weak bond between them a vacuum space is created which prevents the propagation of cracks or prevents them. Plastic particles improve deformation capacity before cracking localization occur. Plastic particles having flake shape act as fibers which prevents cracking.

Replacement of quarry dust beyond $30 \%$ as fine aggregate replacement won't contribute significantly to strength increase [Febin et.al;2019]. Beyond 30\% replacement strength reduces. Quarry dust replacement of 30\% replacement is found to be optimum. Water absorption was also reduced with the inclusion of quarry dust. Beyond $45 \%$ replacement, acid and sulphate penetration was found to reduce but the strength loss was significant. As the air voids were filled with the quarry dust, thermal conductivity was increased. So quarry dust incorporated aerated concrete blocks can't provide necessary thermal insulation. Apart from aerated concrete addition of quarry dust by $30 \%$ replacement is effective for foam concrete also [Gopalakrishnan.R et.al;2020]. Quarry dust addition is found to be effective as a good filler material.

Brittleness and low fracture toughness of AAC blocks can be improved by the usage of fibres [Kalpana, M., and S. Mohith; 2020]. But thermal conductivity is an issue with them (He et,al; 2019). An addition of $1 \%$ rubber powder was found to increase the performance of AAC blocks. There was a slight increase in compressive strength with the addition of rubber powder by $1 \%$ whereas the flexural strength was decreased slightly. Overall, the mechanical property was not that much affected by the addition of rubber powder. Significant reduction was observed in thermal conductivity. It was reduced by $13.8 \%$ by the addition of rubber powder. Rubber powder had a positive impact on microstructure due to its air entrainment. That was a major factor in improving the thermal insulation by rubber powder. Rubber powder improved the porosity also.

Optimum content of wood fiber for AAC block was found to be $0.4 \%$. Unlike the rubber powder wood fiber improved the mechanical strength significantly [He et.al;2019]. AAC block with wood fiber of $0.4 \%$ had compressive strength 1.09 times more than the ones without wood fiber. With the addition of wood fiber beyond $0.4 \%$, the flexural strength was reduced significantly. The toughness was very much improved by the addition of wood fiber. Wood fiber increased the thermal insulation just like the rubber powder. Thermal conductivity was reduced by $13.7 \%$ with wood fiber addition. 
Sustainability, Agri, Food and Environmental Research, (ISSN: 0719-3726), 10(X), 2022:

http://dx.doi.org/

Upto $20 \%$ addition of rice husk ash the compressive strength of AAC increased [Kunchariyakun et.al;2015]. Durability of AAC was improved by the addition of rice husk ash. XRD analysis and SEM analysis was done to properly study the microstructure of the specimen. In the same study aluminium powder as aerating agent was used with varying dosages. All the samples met the ASTM standard class 6.

\section{RESULTS AND DISCUSSIONS}

Addition of GGBFS as SCM is very effective in improving the mechanical properties of aerated concrete. Plastic particles and rubber powder as partial replacement of fine aggregate improves the property of aerated concrete. But the major issue was with the strength improvement. Quarry dust proved to be a good filler material which significantly improves the mechanical strength and enhance the thermal insulation. Creating concrete of low weight having adequate mechanical properties is the major concern. Incorporation of waste materials will help to produce a concrete of eco-friendly characteristics. Future scope of the studies include a detailed analysis on the durability characteristics of aerated concrete and the micro structure study.

\section{REFERENCES}

Chaipanich, A., and P. Chindaprasirt. 2015. The Properties and Durability of Autoclaved Aerated Concrete Masonry Blocks. Eco-Efficient Masonry Bricks and Blocks: Design, Properties and Durability. Elsevier Ltd. https://doi.org/10.1016/B978-1-78242-305-8.0000

Drochytka, Rostislav, and Ester Helanová. 2015. Development of Microstructure of the Fly Ash Aerated Concrete in Time, Procedia Engineering 108: 624-31.

https://doi.org/10.1016/j.proeng.2015.06.189.

Febin, G. Kottukappalli, A. Abhirami, A. K. Vineetha, V. Manisha, R. Ramkrishnan, Dhanya Sathyan, and K. M. Mini. 2019. Strength and Durability Properties of Quarry Dust Powder Incorporated Concrete Blocks, Construction and Building Materials 228: 116793. https://doi.org/10.1016/j.conbuildmat.2019.116793.

Gopalakrishnan, R., V. M. Sounthararajan, A. Mohan, and M. Tholkapiyan. 2020. The Strength and Durability of Fly Ash and Quarry Dust Light Weight Foam Concrete, Materials Today: Proceedings 22 (xxxx): 1117-24. https://doi.org/10.1016/j.matpr.2019.11.317.

He, Tingshu, Rongsheng Xu, Yongqi Da, Renhe Yang, Chang Chen, and Yang Liu. 2019.

Experimental Study of High-Performance Autoclaved Aerated Concrete Produced with Recycled Wood Fibre and Rubber Powder.Journal of Cleaner Production 234: 559-67. https://doi.org/10.1016/j.jclepro.2019.06.276.

Kalpana, M., and S. Mohith. 2020. Study on Autoclaved Aerated Concrete: Review, Materials Today: Proceedings 22 (xxxx): 894-96. https://doi.org/10.1016/j.matpr.2019.11.099. 
Sustainability, Agri, Food and Environmental Research, (ISSN: 0719-3726), 10(X), 2022:

http://dx.doi.org/

Kunchariyakun, Kittipong, Suwimol Asavapisit, and Kwannate Sombatsompop. 2015. Effect of Fine Al-Containing Waste in Autoclaved- Aerated Concrete Incorporating Rice-Husk Ash, Journal of Materials in Civil Engineering 27 (8): 04014220. https://doi.org/10.1061/(asce)mt.1943-5533.0001149.

Pachideh, Ghasem, and Majid Gholhaki. 2019. Effect of Pozzolanic Materials on Mechanical Properties and Water Absorption of Autoclaved Aerated Concrete, Journal of Building Engineering 26 (June): 100856. https://doi.org/10.1016/j.jobe.2019.100856.

Qu, Xiaoling, and Xuguang Zhao. 2017. Previous and Present Investigations on the Components, Microstructure and Main Properties of Autoclaved Aerated Concrete - A Review, Construction and Building Materials 135: 505-16. https://doi.org/10.1016/j.conbuildmat.2016.12.208.

Received: $30^{\text {th }}$ January 2021; Accepted: 14 ${ }^{\text {th }}$ March 2021; First distribution: 01th April 2021 